\title{
Exploring EFL Students' English Reading Habits: Reading beyond Classroom Practice
}

\author{
${ }^{1}$ Karunia Eka Nafilatul Janah* \\ Universitas Negeri Surabaya \\ ${ }^{2}$ Mohammad Adnan Latief, ${ }^{3}$ Sri Andreani \\ Universitas Negeri Malang \\ *Corresponding Author \\ Email: karunia.20044@mhs.unesa.ac.id
}

\begin{abstract}
Some previous studies have proven that having good reading habits is important for students. Regarding the importance of having good reading habits, it is essential that students who learn English as Foreign Language (EFL) to develop good English reading habits. If EFL students have good English reading habits, it will be much easier for them to receive language inputs and produce some language outputs after reading. The study is intended to investigate whether EFL students have good English reading habits as the fact that it is important for EFL students to develop good English reading habits. It covers the students' general attitudes toward reading, the students' amount of practice for reading English books, types of English materials the students read, topics of English texts the students read, number of English books the students read, the students' purposes in reading English materials, and the students' beliefs of English reading habits. This study uses descriptive research survey involving 154 EFL students of a state university in Malang, East Java, Indonesia. The results show that EFL students have developed good English reading habits, but they still need improvement in the frequency of reading practice and the number of books read. Besides, they have positive attitudes toward reading, various kinds of English reading texts and topics to read, various reading purposes, and positive beliefs toward English reading habits. However, it is found that some respondents have difficulties to give fast responses in answering the questions through the questionnaire platform used. Therefore, some suggestions are also given as the recommendations for future researchers related to this field of study.
\end{abstract}

Keywords: Reading habits, English reading habits, EFL students

\section{INTRODUCTION}

Good reading habits of students are defined as a repeated desired reading behavior that becomes the second nature of the students (Iftanti, 2012). In other words, students who form good reading habits are those who love reading and consider reading an activity that has frequent repetition on the daily basis. Some previous studies have proven that having good reading habits is essential. Having good reading habits is important as reading is a means for personal growth; it shapes the imagination, plays a critical role that allows the individual to control language, and plays a role in society (Knoester, 2010). Furthermore, students can get many advantages of reading by being aware that reading habits can increase students' receptive skills in language learning; widen students experience and knowledge (Green \& Hughes, 2006); and develop reading speed, fluency, vocabulary, general knowledge and academic achievement (Chettri \& Rout, 2013). Therefore, it is 
important to have a good reading habit since it can contribute to the improvement of students' language acquisition.

Regarding the importance of having good reading habits, it is essential that students who learn English as Foreign Language (EFL) to develop good English reading habits because they have much direct contact and exposure to English texts and reading materials written in English. In other words, if EFL students have good English reading habits, it will be much easier for them to receive language inputs and also produce some language outputs after reading. Furthermore, it is important to develop EFL students' English reading habits as early as possible in order to get a better understanding of English. Besides through some activities done in the classroom, developing EFL students' English reading habits can also be done through reading activities done outside the class. Therefore, it is important to develop EFL students' English reading habits to make English reading habits a sustainable pattern of behavior in EFL students' daily basis.

Some previous studies about reading habits have been conducted by some researchers. Iftanti (2012) conducted a research that investigated the English reading habits of Indonesian students of EFL in Indonesia involving 546 students of English Department from five state universities in East Java and interview validation. From the study, it can be concluded that most of the EFL students do not indicate to have good English reading habits although they have positive beliefs that reading English can improve their English skills and knowledge and can support their future career and academic success (Iftanti, 2012). Then, another previous study is a survey on reading habits conducted by Putra (2018). It investigated the reading habits of students who have passed all of three extensive courses of English Language Teaching (ELT) program in a state university in Malang; 79 sixth semester students and 100 eighth semester students. The result showed that the students have good reading habits. It is also found that although the students were indicated to have good reading habits based on their positive responses, it still needed to be improved since the quantity of books that they read in a week still needed improvement.

The result of the study conducted by Putra (2018) mentioned in the paragraph above is not in line with the result from another previous study on the same topic conducted by Iftanti (2012) mentioned previously. As a result, based on those previous studies, it is necessary to conduct research about English reading habits that involve EFL students from all semester levels so that it can complete and confirm the findings of previous studies on the related topic. Therefore, this current study is conducted to investigate whether EFL students have good English reading habits as the fact that it is important for EFL students to develop good English reading habits. The English reading habits in this study cover general attitudes toward reading, their amount of practice for reading English books, types of English materials they read, topics of English texts they read, number of English books they read, their purposes in reading English materials, and their beliefs of English reading habits.

\section{METHOD \\ Respondents}

Since the research design used in this study is a descriptive research survey, this study involved 154 EFL students as the respondents. They are students of the 
Department of English at a state university in Malang, East Java, Indonesia. The researchers use stratified random sampling for selecting the respondents who are Department of English students from four semester levels; second, fourth, sixth, eighth. They are 21 second semester students, 31 fourth semester students, 30 sixth semester students, and 72 eighth semester students of 2019/2020 academic year.

\section{Instruments}

The instrument used in this research is an online questionnaire. The information collected by the online questionnaire is the information about the English reading habits of Department of English students at a state university in Malang, East Java, Indonesia. In this research, all variables of the English reading habits are covered appropriately by the questions in the questionnaire. The questionnaire has 12 close-ended questions that are divided into 7 sections of questions about variables of the English reading habits. They are the students' general attitudes toward reading, the students' amount of practice for reading English books, types of English materials the students read, topics of English texts the students read, number of English books the students read, the students' purposes in reading English materials, and the students' beliefs of English reading habits. Some of the questions use a 5-point likert scale that have five answer options which are 'strongly agree', 'agree', 'uncertain', 'disagree', and 'strongly disagree'. Furthermore, other questions have options of statements that respondents have to choose as their answers. Therefore, all respondents are expected to answer all the questions based on their true experiences in reading books, especially any English books other than English course books used in the classroom.

\section{Procedures}

Before the questionnaire was distributed to all respondents, validation from experts was done to make sure that the questionnaire is appropriate and correctly represents the information that the researchers want to have in this research. Based on feedback given by the experts, the questionnaire was revised. The revisions are omitting a question about reading motivation because it is similar to the previous question about reading purpose and erasing a question about opinion on their reading habits since it will be biased if some respondents do not have background knowledge or criterion about it. After validation from experts, a try out for the questionnaire was done. The questionnaire was tried out to 12 respondents, 3 first semester students ( $2.5 \%$ of the population), 3 third semester students $(2.5 \%$ of the population), 3 fifth semester students (2.4\% of the population), and 3 seventh semester students (2.3\% of the population). In the process of try out, the researchers got some suggestions and comments related to the questionnaire. Based on that, the researchers then changed the question "why do you read?" into "what are your beliefs toward reading?" to make the question more specific so that the respondents are not confused in choosing the answers.

\section{Data Collection}

The questionnaire was distributed to 154 respondents. The questionnaire was distributed to the respondents from January 29, 2020 until 9 February, 2020 using online survey platform, Google Form. The researcher shared the link of the questionnaire to the respondents who are in the second, fourth, sixth, eighth 
semester of 2019/2020 academic year. The link of the questionnaire was distributed through personal WhatsApp chats to some of the respondents from each semester levels. After that, they shared the link of the questionnaire to WhatsApp group chats that they have with other students from the same semester levels. As a result, students from each semester levels were able to participate in answering the questions in the questionnaire through the link that they obtained from WhatsApp group chats.

\section{Data analysis}

Data obtained from the data collection process were analyzed. A simple statistical technique was used to analyze the data gathered from the questionnaire. The next data analysis was to find the portion of each variable of reading habits. The five answer options which are 'strongly agree', 'agree', 'uncertain', 'disagree', and 'strongly disagree' are simplified into three categories which are positive, neutral, and negative. The positive category is collected from answers of 'strongly agree' and 'agree'. The neutral category is collected from the answer of uncertain. Then, negative category is collected from answers of 'disagree' and 'strongly disagree'. The result from the analysis is shown in a form of figures and tables. As a result, a conclusion can be drawn from the data frequency and data percentage shown whether the students' English reading habits are categorized as positive, neutral, or negative based on the result from each variables of reading habits stated in the questionnaire which are the students' general attitudes toward reading, the students' amount of practice for reading English books, types of English materials the students read, topics of English texts the students read, number of English books the students read, the students' purposes in reading English materials, and the students' beliefs of English reading habits.

For question number one, two, and three on the students' general attitudes toward reading and question number six on the students' amount of practice for reading English books, if the respondents choose 'strongly agree' or 'agree' as their answers, it is assumed that they have fulfilled the variables of reading habits. Then, uncertain answers mean that respondents have the variables of reading habits, but it is not firmly established or they like reading but not doing it consistently. Besides, if the respondents choose 'disagree' or 'strongly disagree' as their answers, it is assumed that they do not show the variables of reading habits. Therefore, the conclusions can be drawn from the results of all variables of English reading habits whether they have good English reading habits or not.

\section{RESULTS AND DISCUSSION}

\section{The Students' General Attitudes toward Reading}

The main purpose of this study is to identify the students' English reading habits. In other words, this study is aimed to know students' reading habits as reading habits could also promote students productivity and creativity (Gardiner, 2005). Furthermore, reading should be the students' habit because reading could promote good comprehension in acquiring knowledge based on self-experience (Acheaw \& Larson, 2014). The result shows that there are five statements related to the students' general attitudes toward reading. The first statement is about selfclaim as a book reader. The results show that 14 respondents $(9.1 \%$ of the total respondents) strongly agree and 62 respondents (40.3\% of the total respondents) 
agree on self-claim as a book reader. Then, 45 respondents $(29.2 \%$ of the total respondents) choose uncertain as their answer on self-claim as a book reader. Besides, 29 respondents $(18.8 \%$ of the total respondents) disagree and 4 respondents (2.6\% of the total respondents) strongly agree on self-claim as a book reader.

The second statement on the students' general attitudes toward reading is the statement whether they spend their spare time for reading. The result shows that 15 respondents (9.7\% of the total respondents) strongly agree and 58 respondents (37.6\% of the total respondents) agree that they spend their spare time for reading. Furthermore, 48 respondents (31.2\% of the total respondents) answer uncertain for the statement. Besides, 25 respondents (16.2\% of the total respondents) disagree and 8 respondents $(5.2 \%$ of the total respondents) strongly disagree that they spend their spare time for reading.

The third statement on the students' general attitudes toward reading is the statement whether students find reading books an interesting activity. The result shows that 28 respondents ( $18.2 \%$ of the total respondents) strongly agree and 67 respondents ( $43.5 \%$ of the total respondents) agree that they find reading books an interesting activity. Then, 31 respondents $(20.1 \%$ of the total respondents) choose uncertain as their answer for the statement. Besides, 22 respondents $(14.3 \%$ of the total respondents) disagree and 6 respondents (3.9\% of the total respondents) strongly disagree that they find reading books an interesting activity. Therefore, the students' positive responses toward reading hopefully can motivate them to read more books as reading provides experience through which the individual may expand his horizons of knowledge, identity; extend and intensify his interests so as to gain deeper understanding of himself (Rout \& Chettri, 2013).

The fourth statement on the students' general attitudes toward reading is the statement whether students usually read books in electronic version (E-book). The result shows that 23 respondents (14.9\% of the total respondents) strongly agree and 44 respondents (28.6\% of the total respondents) agree that they usually read books in electronic version (E-book). Furthermore, 50 respondents $(32.5 \%$ of the total respondents) answer uncertain for the statement. Besides, 25 respondents ( $16.2 \%$ of the total respondents) disagree and 12 respondents $(7.8 \%$ of the total respondents) strongly disagree that they usually read books in electronic version (E-book).

The fifth statement on the students' general attitudes toward reading is the statement whether students read books in the printed version. The result shows that 35 respondents ( $22.7 \%$ of the total respondents) strongly agree and 59 respondents (38.3\% of the total respondents) agree that they read books in the printed version. Furthermore, 39 respondents $(25.3 \%$ of the total respondents) choose uncertain as their answer for the statement. Besides, 16 respondents $(10.4 \%$ of the total respondents) disagree and 5 respondents (3.2\% of the total respondents) strongly disagree that they read books in printed version. The detail of descriptions for the first, second, and third statement on general attitudes toward reading can be summarized into figure 1 that shows the proportion of the students' concerning attitudes including the summary from those three options.

The five attitudes which are strongly agree, agree, uncertain, disagree, and strongly disagree for the first, second, and third statement can be simplified into three general attitudes; positive, neutral, and negative toward those three statements 
about reading. The following figure shows the proportion of the responses for the positive, neutral, and negative attitude. The figure describes whether students have positive, neutral, or negative attitude toward reading. The result shows that most of the students have positive attitudes toward reading. It constitutes $52 \%$ on the figure 2.

The fourth and fifth statements are statements on the students' preference forms of text books; printed or unprinted forms. For the fourth statements, the result shows that 23 respondents ( $14.9 \%$ of the total respondents) strongly agree and 44 respondents (28.6\% of the total respondents) agree that they usually read books in electronic version (E-book). Then, 50 respondents (32.5\% of the total respondents) answer uncertain for the statement. Besides, 25 respondents $(16.2 \%$ of the total respondents) disagree and 12 respondents ( $7.8 \%$ of the total respondents) strongly disagree that they usually read books in electronic version (E-book). Furthermore, for the fifth statement the result shows that 35 respondents $(22.7 \%$ of the total respondents) strongly agree and 59 respondents (38.3\% of the total respondents) agree that they usually read books in printed version. Then, 39 respondents $(25.3 \%$ of the total respondents) choose uncertain as their answer for the statement. Besides, 16 respondents (10.4\% of the respondents) disagree and 5 respondents $(3.2 \%$ of the total respondents) strongly agree that they usually read books in printed versions. For the better perspective, the result for the fourth and fifth statement is presented in the figure 3 that presents the students' preference forms of textbooks.

Students' preference form of books can be one of factors that contribute in reading activities as Kozminsky and Asher-Sadon (2013) examined in their study the relative contributions of the print (traditional) and the electronic media to literacy development of kindergarten children; both the print and electronic media can foster literacy skills before entering school. Furthermore, their study shows that there was a slight advantage of exposure to print for some of the skills (understanding a story plot, knowledge about print, and vocabulary) over the electronic media (Kozminsky \& Asher-Sadon, 2013).

\section{The Students' Amount of Practice for Reading English Books}

The result shows that there are two statements related to the students' amount of practice for reading English books. The first statement is about students' practice in reading English books whether they like reading English books in their leisure time. The results show that 23 respondents ( $14.9 \%$ of the total respondents) strongly agree and 54 respondents (35.1\% of the respondents) agree that they like reading English books in their leisure time. Then, 57 respondents $(37.0 \%$ of the total respondents) choose uncertain as their answer for the statement. Besides, 13 respondents (8.4\% of the total respondents) disagree and 7 respondents $(4.5 \%$ of the total respondents) strongly agree that they like reading English books in their leisure time. For the better perspective, the result of the statement is presented in figure 4 that presents the students' responses on the statement whether they like reading English books in their leisure time.

The five attitudes above which are strongly agree, agree, uncertain, disagree, and strongly disagree can be simplified into three general attitudes; positive, neutral, and negative toward reading English books in leisure time. The following figure shows the proportion of the responses for the positive, neutral, and negative attitude. The figure describes whether students have positive, neutral, or negative 
attitude toward reading English books in their leisure time. The result shows that most of the students have positive attitudes toward reading English books in their leisure time. It constitutes $50 \%$ on the figure 5 .

The second statement on the students' amount of practice for reading English books is the statement about students' average time of practice for reading English books. The result shows students' length of time or on how many hours the students read English books every day. The results show that the number of students who read English books for more than 5 hours every day is 2 (1.3\% of the total respondents). Furthermore, the number of students who read English books for 4 to 5 hours every day is 10 (6.5\% of the total respondents). Next, the number of students who read English books for 2 to 3 hours are 14 (9.1\% of the total respondents). Then, the number of students who read English books for 1 to 2 hours (more than an hour) every day is 38 ( $24.7 \%$ of the total respondents). Not only that, the number of students who read English books for less than an hour is $26(16.9 \%$ of the respondents). Besides, the number of students who do not always read every day is 64 (41.6\% of the total respondents). For the better perspective, the result of the statement is presented in figure 6 that presents the students' responses on their average time of practice for reading English books.

The findings show the length of time students read English books every day. Based on the result, the students' amount of practice in reading English books is low. It can be seen that 64 students do not always read English books every day. Their average time of reading English books every day is also low as 26 students read English books for less than hour, 38 students read English books for more than an hour or about 1 to 2 hours, 14 students read English books for 4 to 5 hours, 10 students read English books for 4 to 5 hours and only 2 students read English books for more than 5 hours. Based on that fact, although most of the students have positive attitudes toward reading English books in their leisure time, it would be better to increase the amount of practice in reading English books as a habit of reading is established by repeating the desired behavior, reading is practiced regularly every day until it becomes the second nature to the learners (Iftanti, 2015). Therefore, repetition of English reading activities is the key in establishing English reading habits so that students can develop good English reading habits in their daily basis.

\section{The Types of English Materials the Students Read}

The result shows the types of English materials that the students read. The results show that the number of students who read various kinds of reading texts is 69 (44.8\% of the total respondents). Furthermore, the number of students who read fiction texts is 53 (34.4\% of the total respondents). Then, the number of students who read non-fiction texts is 24 (15.6\% of the total respondents). Besides, the number of students who read e-texts is 8 (5.2\% of the total respondents). For the better perspective, the result of the statement is presented in figure 7 that presents the students' responses on types of English materials that they read.

The findings show that most of the students read various kinds of reading texts as presented in figure 7. It can be seen from 69 students who answer it. Besides, 53 students read fiction texts, 24 students read non-fiction texts, and 8 students read e-texts. Types of English materials is one of variables of the English reading habits as Iftanti (2015) stated that good reading habits in English refer to 
behaviors of reading various kinds of English materials which are regularly, permanently, and intentionally conducted so it becomes a part of the EFL students' daily activities. Therefore, seen from the various kinds of English materials they read in their reading practice, it shows that the students are indicated to develop good English reading habits.

\section{The Topics of English Texts the Students Read}

The result shows the topics of English texts that the students like to read. In the questionnaire, students could choose more than an option as their answers for topics of English texts that they like to read. The answer options are education, health, psychology, love, culture, economy, science, and option of "others" that students could fill in by themselves. The results show that the number of students who choose education as one of their topics of English texts is 71 (46.1\% of the total respondents). Furthermore, the number of students who choose health as one of their answer options is 42 (27.3\% of the total respondents). Then, the number of students who choose psychology as one of their answer options is 65 (42.2\% of the total respondents). Next, the number of students who choose love as one of their answer options is 89 (57.8\% of the total respondents).

The number of students who choose culture as one of their answer options is 87 (56.5\% of the total respondents). Not only that, the number of students who choose economy as one of their answer options is 13 (8.4\% of the total respondents). Furthermore, the number of students who choose science as one of their answer options is 35 (22.7\% of the total respondents). Next, for the option of 'others' where students could fill the answers by themselves, it found that 29 students ( $18.8 \%$ of the total respondents) wrote various kinds of topics. For the better perspective, the result is presented in figure 8 that presents the students' responses on the topics of English texts that they like to read. Therefore, by reading various kinds of topics, they can increase and widen their knowledge as reading can build up inspiration/ ideas, promote critical analysis, enhance knowledge, enrich diction, collect detail information, strengthen theory, improve writing quality, and others (Khoirunnisa \& Safitri, 2018).

\section{The Number of English Books the Students Read}

The result shows the number of English books that the students read every week. The results show that 2 students $(1.3 \%$ of the total respondents) read 5 English books or more every week. Furthermore, 13 students $(8.4 \%$ of the total respondents) read 3 to 4 English books every week. Then, 52 students (33.8\% of the total respondents) read 1 to 2 English books every week. Besides, 87 students (56.5\% of the total respondents) do not always read English books every week. For the better perspective, the result is presented in the figure 9 that presents the number of English books that students read every week.

Based on the result, most of the students do not always read English books every week as 87 students or $56.5 \%$ of them answer so as presented in figure 9 . Other than that, 52 students only read one to two English books every week, 13 other students read three to four English books every week, and the number of students who read five English books or more are only 2. Based on such conditions, it can be assumed that students do not read a large number of English books every week. Therefore, the students have to improve their reading habits because good 
reading habits can give some advantages such as developing reading speed, fluency, vocabulary, general knowledge, and academic achievement (Chettri \& Rout, 2013).

\section{The Students' Purposes in Reading English Materials}

The result shows the students' purposes in reading English materials. In the questionnaire, students could choose more than an option as their answers for statements on purposes in reading English materials. The answer options of statements are reading English materials to gain information, for pleasure, to spend spare time, to finish tasks/homework, and to improve English skills. The results show that the number of students who choose reading English materials to gain information as one of their answer options is 96 (62.3\% of the total respondents). Furthermore, the number of students who choose reading English materials for pleasure is 92 (59.7\% of the total respondents). Then, the number of students who choose reading English materials to spend their spare time is 56 (36.4\% of the total respondents). Besides, the number of students who choose reading English materials to finish tasks/homework is 100 (64.9\% of the respondents). Then, the number of students who choose reading English materials to improve their English skills is 72 (46.8\% of the total respondents). For the better perspective, the result is presented in figure 10 that presents the students' responses on their purposes in reading English materials.

Based on the result, the top three purposes of the students in reading English materials are to finish task/homework, to gain information, and for pleasure as presented in figure 10. Other than those three purposes, the students also read English materials to improve their English skills and to spend their spare time. The fact that their purpose in reading English materials is to finish task/homework is in line with a study by Iftanti (2012) that investigated EFL students' English reading habits. Her study showed that most of the respondents, $60.07 \%$ of them, read English books for the sake of assignments. Therefore, reading English materials hopefully can successfully contribute in completing the students' task or assignments so that they can finish their study well.

\section{The Students' Beliefs of English Reading Habits}

The result shows the students' beliefs of the English reading habits. In the questionnaire, students could choose more than an option as their answers for statements on their beliefs of the English reading habits. The options are that students believe that reading English can improve their English skills, improve their knowledge, support their future career, and support their academic success. The results show that the number of students who believe that reading English books can improve their English skills as one of their beliefs of the English reading habits is 133 ( $86.4 \%$ of the total respondents).

Next, the number of students who believe that reading English books can improve their knowledge as one of their beliefs of the English reading habits is 132 ( $85.7 \%$ of the total respondents). Then, the number of students who believe that reading English books can support their future career as one of their beliefs of the English reading habits is 71 ( $46.1 \%$ of the total respondents). Next, the number of students who believe that reading English books can support their academic success as one of their beliefs of the English reading habits is 91 (59.1\% of the total respondents). For the better perspective, the result is presented in the figure 11 that 
presents the students' responses on their beliefs of the English reading habits.

The results show that most of the students have positive beliefs of the English reading habits as presented in figure 11 . The positive beliefs that the students agree with the most are reading English books can improve their skills and knowledge. The other positive beliefs of the English reading habits that they have are reading English books can support their academic success and future career. The finding of this study is in line with a study conducted by Prijana (2013) who found that the students' belief on reading can be effective in many aspects of their lives; they believed that reading can enhance and develop their mental capacity and imaginary world respectively, give aesthetic pleasure, develop multi reasoning, open the door of the unknown world, enable them express their feelings and gain the habit of fast reasoning. Therefore, it can be concluded that the students have positive beliefs of reading English books so that, by having those positive beliefs, they can possibly improve their English reading habits to have good English reading habits in their daily practices.

\section{CONCLUSION}

Based on the research findings and discussion above, the researchers state several reflective points. The students show positive attitudes toward reading, prefer printed books to electronic books, like to spend their leisure time for reading English books, do not always read English books every day for most of them while some other of them read English books for less than an hour up to more than an hour every day, read various kinds of reading texts; fiction texts, non-fiction texts, and e-texts, read various topics of English texts such as love, culture, and education, do not always read English books every week for most of them while some of them only read one to two English books every week, have various purposes in reading English materials; to finish task/homework, to gain information, and for pleasure, have positive beliefs of the English reading habits; can improve their skills and knowledge and support their academic success and future career. Finally, this study concludes that the students have developed good English reading habits, but they still need improvement especially in the frequency of practice in reading English books and the number of English books read. The limitation in this study is found when some respondents have difficulties to give fast responses in answering questions through the online questionnaire platform used. Therefore, future researchers who want to conduct research in the similar field of this study are suggested to be more careful in choosing the platforms to spread the questionnaire.

\section{REFERENCES}

Acheaw, M. O. \& Larson, A. (2014). Reading habits among students and its effects on academic performance: A study of students of Koforidua Polytechnic. Library Philosophy and Practice (e-journal): University of NebraskaLincoln. http://digitalcommons.unl.edu/libphilprac/1130?utm_source=digitalcommon sunl.edu\%2Flibphilprac\%2F1130\&utm_medium=PDF\&utm_campaign=PD FCoverPage.

Chettri, M. K. \& Rout, S. K. (2013). Reading habits - An overview. IOSR Journal Of Humanities And Social Science (IOSR-JHSS), 14(6), 13-17. 
http://iosrjournals.org/iosr-jhss/papers/Vol14-issue6/C01461317.pdf.

Gardiner, S. (2005). Building student literacy through sustained silent reading. Alexandria: Association for Supervision and Curriculum Development.

Green, P. \& Hughes, M. (2006). Parents' and teachers' interventions in children's reading. British Educational Research Journal, 24(4), 383-398. https://doi.org/10.1080/ 0141192980240402.

Iftanti, E. (2012). A survey of the English reading habits of EFL students in Indonesia. TEFLIN Journal, 23(22), 130-138. http://dx.doi.org/10.15639/ teflinjournal.v23i2 .

Iftanti, E. (2015). What Makes EFL students establish good reading habits in English. International Journal of Education and Research, 3(5), 365-374. https://www.ijern.com/journal/2015/May-2015/31.pdf .

Khoirunnisa \& Safitri, I. D. (2018). Reading habits and its effect on academic writing skill: A study of master degree students. JELE (Journal of English Language and Education), 4(1), 43-50. http://ejurnal.mercubuanayogya.ac.id/ index.php/jele/ article/view/298.

Knoester, M. (2010). Independent reading and the 'social turn': How adolescent reading habits and motivation relate to cultivating social relationships. Networks: An On-line Journal for Teacher Research, 12(1), 1-13. http://journals.sfu.ca/uwmadison/ index.php/networks/issue/view/38 .

Kozminsky, E., \& Asher-Sadon, R. (2013). Media type influences preschooler's literacy development: E-book versus printed book reading. Interdisciplinary Journal of E-Learning and Learning Objects, 9, 231-245. http://www.ijello.org/ Volume9/IJELLOv9p233-247Kozminsky0865.pdf.

Priajana, N. (2013). Student teachers' reading habits and preferences. Journal on English as a Foreign Language (JEFL), 3(2), 71-76. https://doi.org/ 10.23971/jefl.v3i2.65. 


\section{APENDICES}

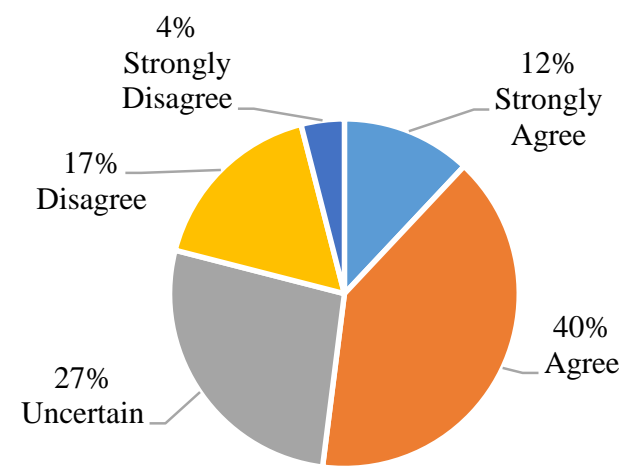

Figure 1. The students' general attitudes toward reading

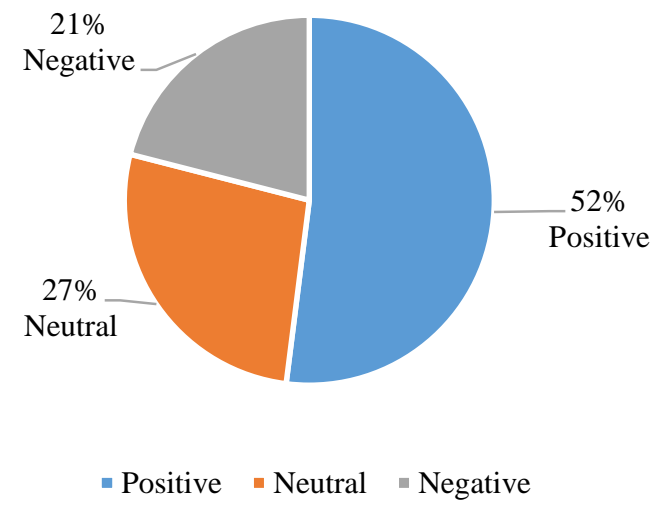

Figure 2. The proportion of positive, neutral, and negative responses on the students' general attitudes toward reading

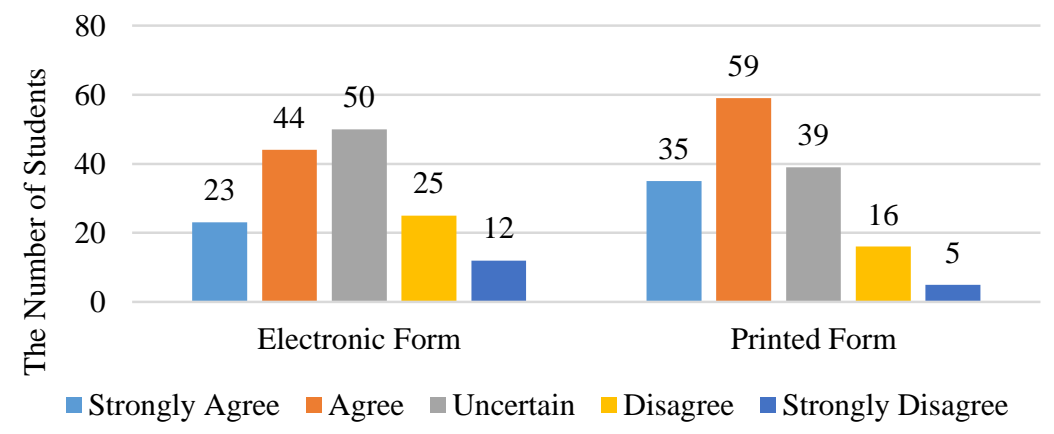

Figure 3. The students' preference forms of text books 
Journal of English Teaching Adi Buana, Vol. 06 No. 01, April 2021

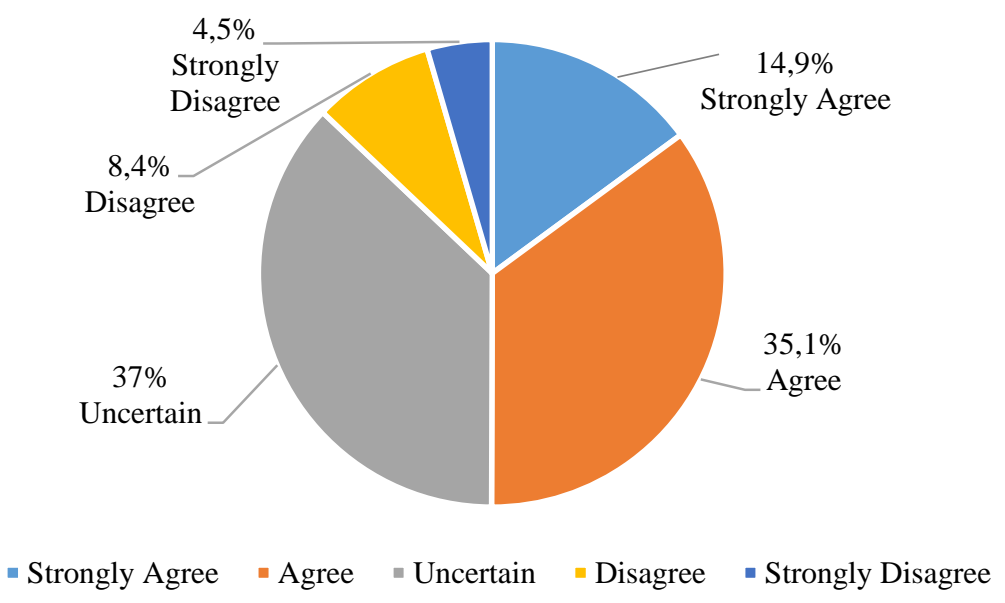

Figure 4. The students' responses on reading English books in leisure time

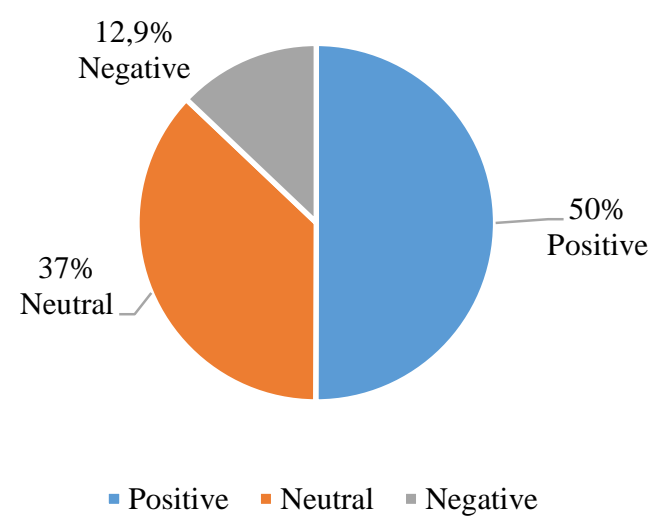

Figure 5. The proportion of positive, neutral, and negative attitudes toward reading English books in leisure time

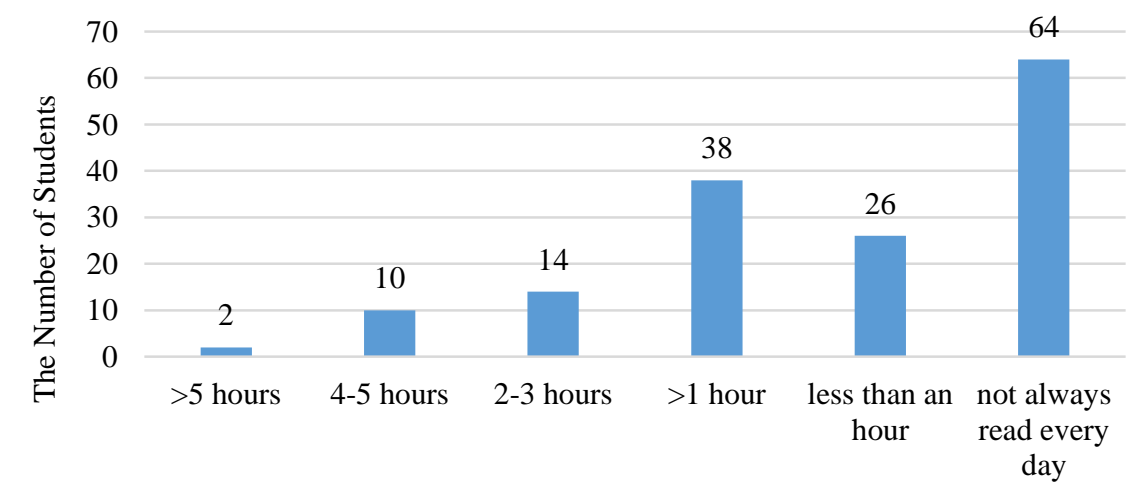

The Length of Time

Figure 6. The students' average time of practice for reading English books 
Exploring EFL Students' English Reading Habits: Reading beyond Classroom Practice

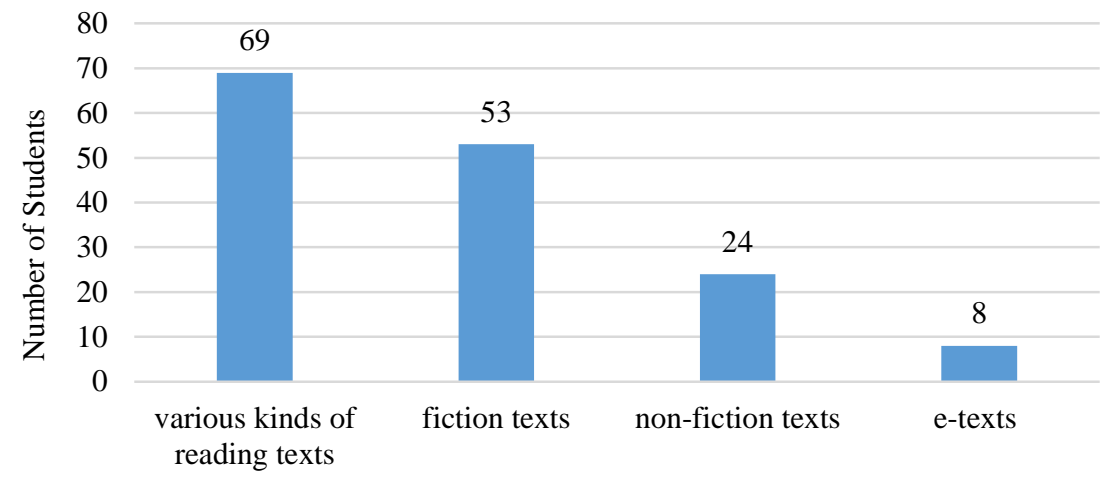

Figure 7. The types of English materials the students read

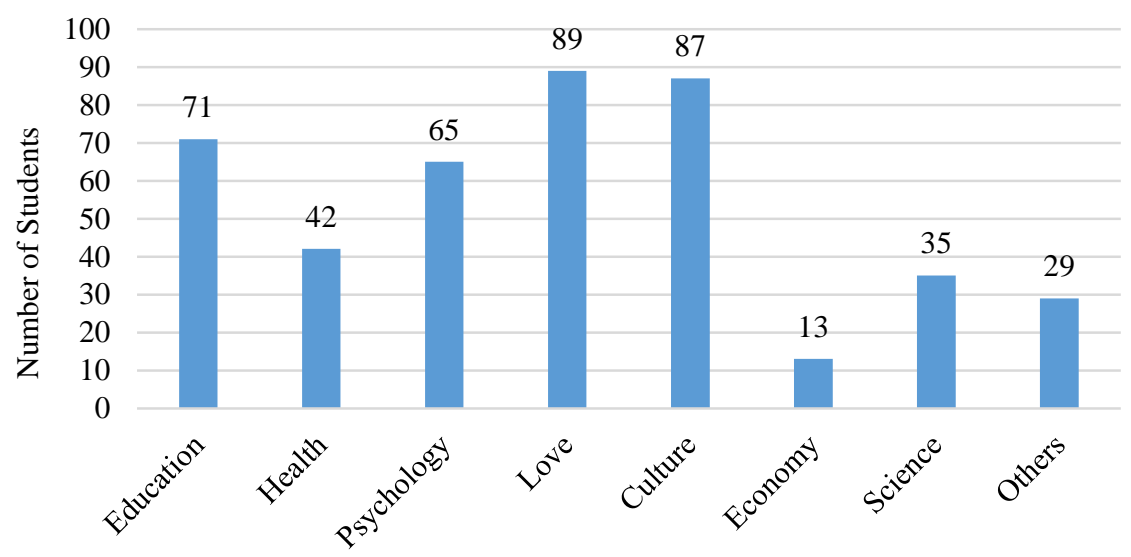

Figure 8. The topics of English texts the students read

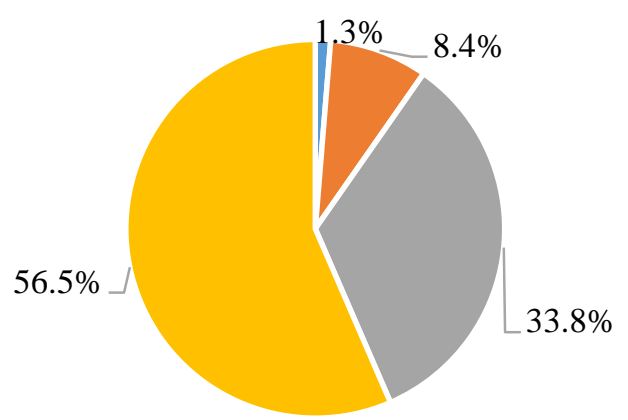

$$
\begin{array}{ll}
\text { - } 5 \text { English books or more } & =3 \text { to } 4 \text { English books } \\
\text { - } 1 \text { to } 2 \text { English books } & \text { not always read English books }
\end{array}
$$

Figure 9. The number of English books the students read 
Journal of English Teaching Adi Buana, Vol. 06 No. 01, April 2021

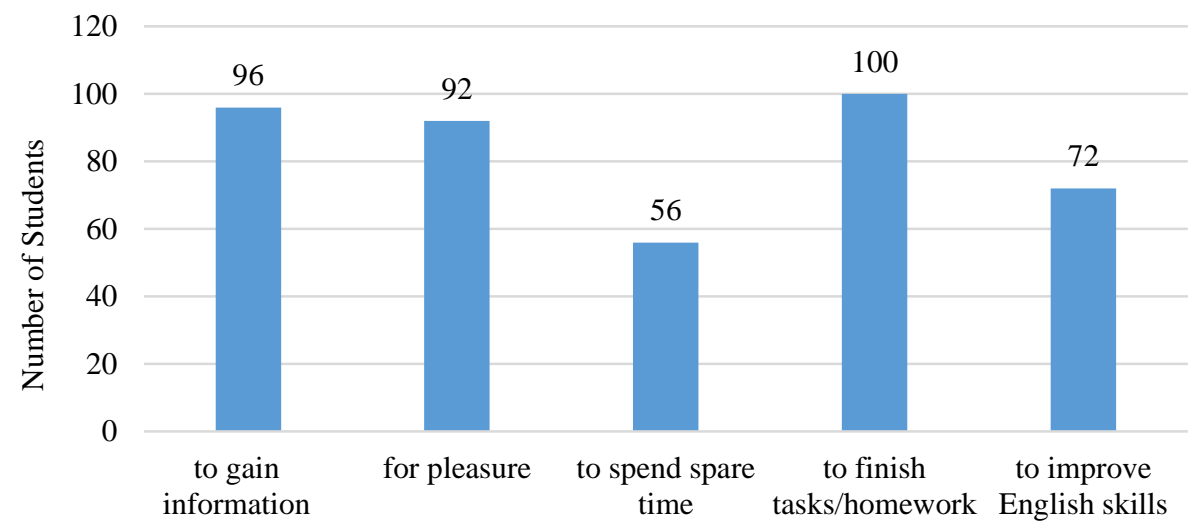

Figure 10. The students' purposes in reading English materials

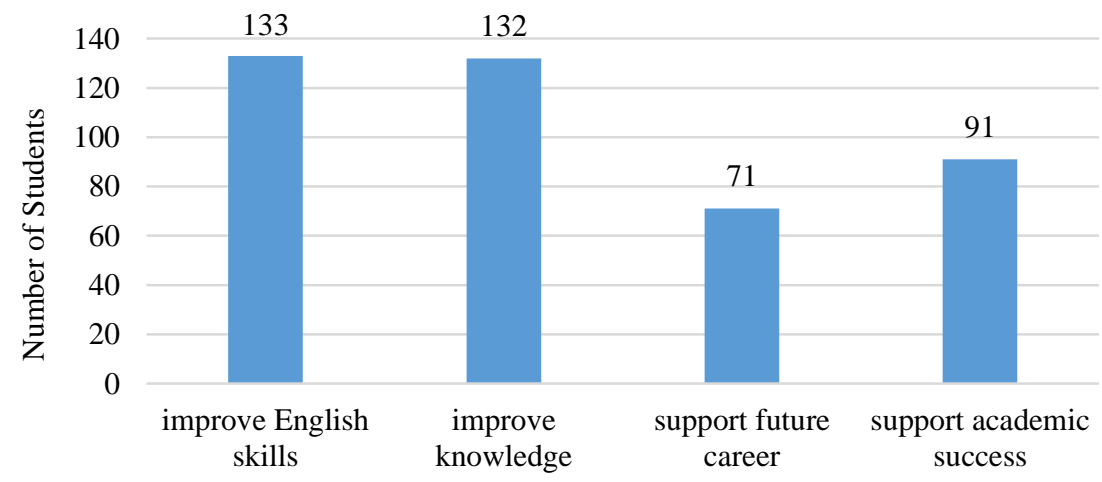

Figure 11. The students' beliefs of reading English books 